\title{
The effects of demographic characteristics and public healthcare systems on COVID-19 mortality risk in the Global South: GIS-based and artificial neural network techniques
}

Research

Keywords:

Posted Date: April 12th, 2021

DOI: https://doi.org/10.21203/rs.3.rs-351254/v2

License: (1) This work is licensed under a Creative Commons Attribution 4.0 International License. Read Full License 


\section{Abstract}

The authors have requested that this preprint be withdrawn due to erroneous posting.

\section{Full Text}

The authors have withdrawn this preprint from Research Square. 